\title{
ANALYSIS OF THE QUALITY OF PUBLIC SERVICE IN THE REGIONAL SECRETARIAT OF SOUTHEAST MALUKU REGENCY, INDONESIA
}

\author{
Rentanubun Lusia \\ Sekolah Tinggi IImu Admiminstrasi (STIA) Langgur, Indonesia \\ E-mail: rentanubunlusia59@gmail.com
}

\begin{abstract}
As decentralized country, the Indonesian government has given authority to each region to manage its resources as much as possible. In this case, the regional government together with its apparatus work together to provide the best service to the community, including the Southeast Maluku district government. However, in its implementation, the services provided by the regional government cannot always satisfy the entire community. This is also felt by the people of Southeast Maluku district. This study describes the quality of public services in the Southeast Maluku district secretariat and alternative solutions through increasing bureaucratic professionalism in the Southeast Maluku district secretariat to improve the quality of public services. This research uses a qualitative approach with a case study method. As for the data collection techniques used in this study, namely interviews, observation, and documentation. The collected data were analyzed using the Miles and Huberman theory that included three activities, namely data reduction, data presentation, and drawing conclusions/verification. This study uses indicators of responsiveness, reliability, and accountability to measure the quality of public services in the regional secretariat o the district o Southeast Maluku. Based on the result of the study, the researchers concluded that the public services contained in the Southeast Maluku district secretariat were not optimal.
\end{abstract}

\section{KEY WORDS}

Quality, public service, Southeast Maluku, regional government.

The spirit of reformation has transformed Indonesia into a de-centralized country, which gives great authority to districts/cities to manage their resources and use them as capital to overcome development problems in the regions. Since the issuance of Act No. 22/1999 then later replaced by Law No. 32/2004, local governments have made various efforts to improve public services to produce services that faster, more precise, cheaper, non-discriminatory, and transparent. However, in reality the community is still positioned as a powerless and marginalized party in the service framework (Kendall et al.,2000; Rifkin, 2003; Kurniawan, 2005; Tew, 2006; Mason, 2007; Wallace, 2010; Smith, 2019; Narayanan \& Bharadwaj, 2019).

The phenomenon of the government service sector that led to public dissatisfaction as consumers, one of them occurred in the Regional Secretariat of Southeast Maluku Regency/District. Based on initial observations made by researcher, the public service that occurred at the Regional Secretariat of Southeast Maluku Regency not yet optimal. This can be seen from several symptoms that are often encountered, namely (1) complicated public service procedures, difficult to understand and difficult to implement; (2) the implementation of public services is not completed within the allotted time; (3) public service products are not received correctly and appropriately; and (4) there is no discipline, courtesy, and friendliness in providing sincere services to the community.

The contributing factor is the lack of professionalism of employees indicated by symptoms, among others (1) employees do not yet have the knowledge / understanding of the tasks and functions they perform; (2) not yet have the skills to apply the role to the public; (3) not yet have social responsibility in carrying out their duties, (4) cannot yet control themselves when dealing with the community, and (5) the existence of community sanctions in the form of complaints as result of the lack of service provided. 
By referring to the above problems, the researcher is interested in conducting research on the reasons, causes, and solutions for the lack of quality public services held by the bureaucrat apparatus at the Regional Secretariat of the Regency of Southeast Maluku. This study aims to find out the description of various problems that arise, identify the factors that influence, and alternative solutions related to the implementation of public services at the Regional Secretariat of Southeast Maluku Regency/District.

In Kepmenpan No. 81/1993, service is a form of service activity carried out by central and regional government agencies, BUMN and BUMD in the form of goods and services in the context of meeting the needs of the community in accordance with applicable laws and regulations. Furthermore, according to Kepmenpan No. 63/KEP/M.PAN/7/2003, public services are all service activities carried out by public service providers as an effort to meet the needs of service recipients and the implementation of statutory provisions. Based on the above understanding, the government is obliged to provide the best service in creating public welfare. The community has the right to get the best service from the government because the community has also given funds in the form of payment of taxes, fees, etc.

Regarding with the quality of service, Albrecht and Zemke (in Dwiyanto, 2005; Grönroos, 2019; Dubey \& Sahu, 2019, Gopalan et al., 2019; Thambusamy \& Palvia, 2018; Bryson, 2018) stated that the quality of public services is the result of the interaction of various aspects, namely service systems, human resources as service providers, strategy, and customer (Razak et al., 2016). Quality refers to everything that satisfies the customer, therefore, a new product can be said to be of good quality if it is in accordance with the wishes of the customer, can be utilized properly, and is produced in a good and correct way. The quality of public services is strongly influenced by factors of organizational structure, the ability of the apparatus, service systems, and service facilities. These factors are interrelated with one another (inseparable) in influencing and determining the quality of services provided by the government. The better the four factors are optimized, then the better the quality of public services and the more it can satisfy the community as the users of the service.

The readiness of the local government apparatus in carrying out its duties and authorities is highly demanded by its professionalism. The professionalism of the government bureaucracy is defined as matters relating to the skills and special abilities to carry out processes and systems that are created rationally, to guarantee mechanisms and systems of work that are orderly, certain, and easily controlled in governance and development that are planned and carried out. In connection with this, the professionalism of the regional government bureaucracy is highly desired by all people so that the implementation of local government authority in providing services to the community can be satisfactory in accordance with the message of the reformation agenda

\section{METHODS OF RESEARCH}

This research was conducted at the Regional Development Planning Agency of Southeast Maluku Regency. The approach used is a qualitative approach with a case study method. According to Moleong (2003) a qualitative approach is defined as a research procedure that produces descriptive data in the form of written or oral words from people and observed behavior. Meanwhile, descriptive research is research that gives a detailed explanation of a phenomenon. This study describes the quality of public services in the Regional Secretariat of the Southeast Maluku Regency and alternative solutions through the improvement of bureaucratic professionalism in the Regional Secretariat of Southeast Maluku Regency to improve the quality of public services.

The main informant sources in this study were 11 people, consisting of the Head of the Agency and the Community (10 people). As for the data collection techniques used in this study, namely interviews, observation, and documentation. The data collected was analyzed using Miles and Huberman's theory consisting of three activities, namely data reduction, data presentation, and drawing conclusions / verification. 


\section{RESULTS AND DISCUSSION}

After the Independence of the Republic of Indonesia, the Southeast Maluku Region is part of South Maluku. In 2000, the Southeast Maluku Regency had been divided into two Districts/Regencies, respectively Southeast Maluku Regency and West Southeast Maluku Regency. Southeast Maluku Regency is supervising 3 (three) Subdistricts, respectively Kei Kecil Subdistrict, Kei Besar Subdistrict, and P.P. Aru Subdistrict, while the West Southeast Maluku Regency is supervising 5 (five) other Subdistricts.

Then, in 2003 Southeast Maluku Regency was re-expanded into two Districts/Regencies, namely Southeast Maluku Regency and Aru Islands Regency. In 2007, another division occurred with the issuance of Act Number 31 of 2007 concerning the establishment of Tual City in Maluku Province and therefore, then determined the Southeast Maluku Regency Regional Regulation No. 02 of 2009 concerning the removal of the Capital of Southeast Maluku Regency from the territory Tual City to Langgur in Southeast Maluku Regency.

Southeast Maluku Regency according to Astronomy is located between $5^{0}$ to $6,5^{0}$ south latitude and $131^{\circ}$ to $133,5^{\circ}$ east longitude. As for the geographical location of Southeast Maluku Regency is bordered by the Arafura Sea (south), South Irian Jaya (north), Aru Islands (east), and the Banda Sea and northern part of the Tanimbar Islands (west). The area of Southeast Maluku Regency is $+7.856,70 \mathrm{~km}^{2}$, with land area $+4.676,00 \mathrm{~km}^{2}$ and water area $+3.180,70 \mathrm{~km}^{2}$.

Meanwhile, based on the topography, Kei Kecil Island is located at an altitude of +100 $\mathrm{m}$ above sea level. Some low hills in the middle and north reach $115 \mathrm{~m}$. Kei Besar Island is hilly and mountainous which extends along the island with an average altitude of $500-800 \mathrm{~m}$ with Mount of Dab as the highest peak. Lowland is a narrow path along the coast. According to the geological map of Indonesia (1965), Island/Islands in Southeast Maluku formed/ composed of soil and rock, there were 3 types of soil and 5 types of rock, as listed in the table below.

Table 1 - Distribution of Soil / Rock Types on the Islands in Southeast Maluku Regency

\begin{tabular}{|c|c|}
\hline Kinds of Land/Rock & Kinds of Rock \\
\hline 1 & 2 \\
\hline Podzolik & Aluvium Undak; Terumbul Coral \\
Rensina & Seklis Habluk; Paleogen \\
Lithasol & Paleozoikum \\
\hline
\end{tabular}

Source: Basic patterns of Southeast Maluku Regency in Southeast Maluku.

The climate in Southeast Maluku is influenced by the Banda Sea, Arafura Sea, and the Indonesian Ocean and Irian Island in the East and the Australian Continent in the South. The state of the season takes place regularly, where the east season (dry season) runs from April to October. While the west season (rainy season) lasts from October to February. In 2009 the overall rainfall in Southeast Maluku Regency equal to $2.615 \mathrm{~mm}$ per year or an average of $217,9 \mathrm{~mm}$ per month with a total of 193 rainy days or an average of 16,1 rainy days per month. Based on Agro-climate classification according to Oldeman, Irsal, and Muladu (1981), in Southeast Maluku there are agro-climate zones and C2 zones with wet months of 5-6 months and dry months of 4-5 months.

The Kei Kecil Subdistrict Office is a regional work unit in Southeast Maluku Regency which has the main task of carrying out government activities in the sub-district. The working area of Kei Kecil Sub-District is under the responsibility of the Regent of Southeast Maluku. Based on its main tasks, the Kei Kecil Subdistrict office performs a number of functions, among others (1) assist the regent in carrying out governance in his working area; (2) ensure order of social life in the region; and (3) carrying out community empowerment tasks in various aspects. Based on its function, structurally the Kei Kecil sub-district office consists of the sub-district head, the sub-district secretary, the government section, the public order and peace section; and the village community empowerment section. 
As for the functions of the Southeast Maluku Regency National Education Office carry out, covering (1) formulating technical policies in the field of education; (2) provide licensing and implementation of public services in the field of education; (3) fostering technical implementation units in the education field; (4) managing administration; and (5) carry out other tasks according to the field.

Meanwhile, the PUP2E office has the task of carrying out autonomy and assistance matters in the fields of bina marga, water resource, cipta karya, spatial planning, housing, as well as mining and energy. In carrying out its duties, the PUP2E office also carry out functions, among others (1) formulating technical policies in the fields of bina marga, water resource, cipta karya, spatial planning, housing, mining and energy; (2) provide licensing and implementation of public services in the areas of highways/ bina marga, water resource, cipta karya, spatial planning, housing, mining and energy; (3) technical guidance in the areas of highways/bina marga, water resource, cipta karya, spatial planning, housing, mining, and energy; (4) managing official administration; dan (5) carry out other tasks in the field of highways/bina marga, water resource, cipta karya, spatial planning, housing, mining and energy given by the regent in accordance with their duties and functions.

In another part, the regional development planning agency as an element of regional government planners has the main task of formulating regional development policies and coordinating the preparation of development plans of each regional work unit. The Southeast Maluku regional development planning agency perform the functions, namely (1) formulating regional planning and investment policies; (2) coordinate the preparation of plans that contain the vision, mission, goals, strategies and program policies; (3) controlling the activities of each regional work unit, (4) managing the administration of the agency, and (5) carry out other tasks in the area of regional planning given by the regent in accordance with their duties and functions.

Then, the regional staffing agency based on Southeast Maluku Regent Regulation number 51 of 2009 has the main task of carrying out the decentralization task in the field of staffing, education, and training. The main function behind the main tasks, namely (1) formulating technical policies within the scope of staffing, education, and training; (2) support the implementation of local government in the field of staffing, education, and training management (3) managing the agency administration, and (4) carry out other tasks in the field of staffing, education, and training provided by the regent in accordance with their duties and functions.

Further, the main task and function of the civil service police station based on the Southeast Maluku Regency Regional Regulation number 08 of 2004 is to carry out the tasks of decentralization in the field of order and enforcement of regional regulations, disaster management as well as information and counseling for the creation of security and public order. The main functions behind these main tasks, among others (1) formulating technical policies within the scope of order and enforcement of regional regulations; (2) provide instructions for administration in the field of order and enforcement of regional regulations; (3) planning operational tasks in the field of fire fighting; (4) planning operational tasks in the field of information and counseling, and (5) carry out other tasks in the field of peace.

Further, the regional library and archives office based on the Southeast Maluku Regent's Regulation number 57 of 2009 has the main task of carrying out the tasks of the regional government in the field of guidance and management of libraries, archives, and documentation. The main functions carried out include (1) implementing technical policies on libraries, archives, and documentation; (2) carry out supporting tasks in the regional government administration in the field of libraries, archives, and documentation; and (3) managing office administration.

\section{DISCUSSION OF RESULTS}

The quality of public services is the result of interaction from various aspects, including service systems (Lindgren et al., 2019; Torfing et al., 2019; Al Ahbabi et al., 2019), human resources as service providers, as well as strategies and customers (Wangila. \& Kiiru, 2019; 
Asokan et al., 2019; Kelloway \& Myers, 2019). the performance the organization performance is improved when the human resource is empowered is participation to achieve goals, commitment, and greater authorities and responsibilities in decision making process (Triatmanto et al., 2010). The response in this study was seen from several aspects, including complaints from the public about the services provided, the attitude of the apparatus in responding to complaints and various actions of the apparatus to provide service satisfaction.

Visitors gave an appreciation on the services provided by the government apparatus in the scope of the national education department of Southeast Maluku Regency. Leaders of agencies either services, agencies, offices, and leaders of sub-district offices recognize this success. Most of them admit that the services provided tend to be good because they have followed the Standard Operating Procedure (SOP). Regarding to security and order, the services provided tend to be arrogant and eliminate sympathy from the community. This reality provides a concrete illustration of the paradigm shift in public services that occurred in Southeast Maluku Regency. As a result, although it is still far from expectations, the service provided has become something new where employees have been able to change mindsets, together with the shifting era that is happening in this nation. Priyayi/ upper classes mentality is no longer the identity of civil servants, because slowly but surely, civil servants in Southeast Maluku increasingly show themselves as public servants. Before the reformation, employees showed themselves as the people to be served, not those who served the community. However, the reformation era has instilled a culture of service within the apparatus.

Reliability is one of the important indicators used to measure the quality of public services (Yang \& Northcott, 2019; Biranvand et al., 2019; Ojo, 2019). In relation to the reliability indicators, which carried out by the office of Kei Kecil sub-district, national education office, public works, housing, mining and energy/ pekerjaan umum, perumahan, Pertambangan dan Energi (PUP2E) office, regional development planning agency, the regional staffing agency, the civil service police station, and the library office and regional archive of Southeast Maluku Regency to create quality services is through the acceleration of time, process, and accuracy of use in each type of service.

This indicator shows a number of diverse opinions. This can be caused not only by the perceived service, but the rest indicated there is a "certain closeness" between the apparatus and the public being served, so they tend to be satisfied more than other communities. The community as service users and the government bureaucracy as servants must understand the importance of the appropriateness of the designation and services provided. This relates to the awareness of non-discrimination without eliminating empathy for the special conditions experienced by customers who have rational obstaclesl. Ideally, such treatment requires direct explanation to other communities so that it does not cause counterproductive bias or later then considered as form of discrimination.

Accountability can be interpreted as a service that can be accounted for in accordance with statutory provisions (Carpenter \& Feroz, 2001; Jones \& Pendlebury, 2004). In this research, accountability can be seen from aspects that include service references used by the bureaucratic apparatus in the process of public service delivery. References of services, often known as Standard Operating Procedures (SOPs) are used to guarantee the quality and suitability of services with the needs of the community for these services.

In general, accountability for public service delivery in Kei Kecil Sub-district, national education office, public works, housing, mining and energy/ pekerjaan umum, perumahan, Pertambangan dan Energi (PUP2E) office, regional development planning agency, the regional staffing agency, the civil service police station, and the library office and regional archive which oriented to community as service users is still quite weak. Officials in providing services still apply unilateral values or norms such as they tend to prioritize regulations rather than the interests of the community. There is a general trend that in the delivery of services always refers to the Standard Operating Procedure (SOP), where this is become the only measure of service success. 


\section{CONCLUSION AND RECOMMENDATIONS}

Based on the explanation stated above, some conclusions the quality of public services in the regional secretariat of Southeast Maluku Regency is still qualitatively low. This happened as a result of the shift in the paradigm of public service from the attitude of employees as people served to be public servants. Reformation has changed the culture of service like this, but the shifts that occur not spontaneous and sporadic. Services provided by the bureaucratic apparatus in the regional secretariat of Southeast Maluku Regency have not been provided appropriately. This can be seen through the discriminatory attitude and the disappearance of empathy from the servants, and the provision of services by the bureaucratic apparatus in regional secretariat of Southeast Maluku regency in general can be said is not yet accountable, because the resources either human and material has not yet been allocated evenly in all Regional Apparatus Work Unit/SKPD.

Referring to the above conclusion, the authors propose some suggestions, among others, the need for acceleration of work culture adaptation of modern government organization, so that bureaucratic apparatus in Southeast Maluku region can actually appear as a public servant, bureaucracy apparatus in the regional secretariat of Southeast Maluku Regency is required to understand its main tasks and functions, so that the implementation of service tasks not only meets the standards but the rest can be felt by the people who need services. And regional government should be more oriented towards the development of material resources and human resources democratically, and the leadership model must shift from power to the expertise approach (from macho to maestro), as well as being democratic, close to subordinates, and applying a humanistic bureaucratic model that places humans in their proportions.

\section{REFERENCES}

1. Al Ahbabi, S. A., Singh, S. K., Balasubramanian, S., \& Gaur, S. S. (2019). Employee perception of impact of knowledge management processes on public sector performance. Journal of Knowledge Management, 23(2), 351-373.

2. Asokan Ajitha, A., Sharma, P., Kingshott, R. P., Maurya, U. K., \& Kaur, A. (2019). Customer participation and service outcomes: mediating role of task-related affective well-being. Journal of Services Marketing, 33(1), 16-30.

3. Biranvand, A., Ghaffari, S., \& Haghirosadat, S. J. (2019). Analyzing the Effect of Delighting Services on the Loyalty of Public Library Users: A Case Study. Library Philosophy and Practice, 0_1-16.

4. Bryson, J. M. (2018). Strategic planning for public and nonprofit organizations: A guide to strengthening and sustaining organizational achievement. John Wiley \& Sons.

5. Carpenter, V. L., \& Feroz, E. H. (2001). Institutional theory and accounting rule choice: an analysis of four US state governments' decisions to adopt generally accepted accounting principles. Accounting, organizations and society, 26(7-8), 565-596.

6. Dubey, P., \& Sahu, S. K. (2019). Effect of Service Quality on Perceived Value, Satisfaction and Loyalty of Customers: A Study on Selected Hospitals of Chhattisgarh.

7. Dwiyanto, A. (2008). Reformasi birokrasi publik di indonesia, pusat studi kependudukan dan kebijakan.

8. Gopalan, G., Hooley, C., Winters, A., \& Stephens, T. (2019). Perceptions among child welfare staff when modifying a child mental health intervention to be implemented in child welfare services. American journal of community psychology.

9. Grönroos, C. (2019). Reforming public services: does service logic have anything to offer?. Public Management Review, 21(5), 775-788

10. Jones, R., \& Pendlebury, M. (2004). A theory of the published accounts of local authorities. Financial Accountability \& Management, 20(3), 305-325.

11. Kelloway, E. K., \& Myers, V. (2019). Leading the service-profit chain: how leaders' behaviors can affect customer experience. Examining the Role of Well-being in the 
Marketing Discipline (Research in Occupational Stress and Well Being, Vol. 17), Emerald Publishing Limited, 71-90.

12. Kendall, E., Buys, N., \& Larner, J. (2000). Community-based service delivery in rehabilitation: the promise and the paradox. Disability and rehabilitation, 22(10), 435-445.

13. Keputusan MENPAN Nomor 63 Tahun (2003). tentang Pedoman Umum Penyelenggaraan Pelayanan Publik.

14. Kurniawan, Agung. (2005). Transformasi Pelayanan Publik, Yogyakarta: Pembaharuan.

15. Lindgren, I., Madsen, C. Ø., Hofmann, S., \& Melin, U. (2019). Close encounters of the digital kind: A research agenda for the digitalization of public services. Government Information Quarterly.

16. Mason, R. (2007, July). Building women's social citizenship: A five-point framework to conceptualise the work of women-specific services in rural Australia. In Women's Studies International Forum (Vol. 30, No. 4, pp. 299-312). Pergamon.

17. Moleong, Lexy j. (2003). Metodologi Penelitian Kualitatif, Bandung: Remaja Rosdakarya.

18. Narayanan, P., \& Bharadwaj, S. (2019). Whose ethics counts? Ethical issues in community development and action research with communities facing stigmatisation. Ethics, equity and community development, 103.

19. Ojo, T. K. (2019). Quality of public transport service: An integrative review and research agenda. Transportation Letters, 11(2), 104-116.

20. Peraturan Bupati Maluku Tenggara Nomor 38 Tahun 2009.

21. Razak, I., Nirwanto, N., \& Triatmanto, B. (2016). The impact of product quality and price on customer satisfaction with the mediator of customer value. Journal of Marketing and Consumer Research, 30(1), 59-68.

22. Rifkin, S. B. (2003). A framework linking community empowerment and health equity: it is a matter of CHOICE. Journal of health, population and nutrition, 168-180.

23. Smith, S. (2019). What Does A Marginalized Community Say About Its Experiences In A Two-Year, Service-Learning Project?.

24. Tew, J. (2006). Understanding power and powerlessness: Towards a framework for emancipatory practice in social work. Journal of social work, 6(1), 33-51.

25. Thambusamy, R., \& Palvia, P. (2018). US Healthcare Provider Capabilities and Performance: the Mediating Roles of Service Innovation and Quality. Information Systems Frontiers, 1-21.

26. Torfing, J., Sørensen, E., \& Røiseland, A. (2019). Transforming the public sector into an arena for co-creation: Barriers, drivers, benefits, and ways forward. Administration \& Society, 51(5), 795-825.

27. Triatmanto, B., Zain, D., Troena, E. A., \& Rahayu, M. (2010). Peran Pemberdayaan Sumber Daya Manusia dalam Peningkatan Kinerja Organisasi melalui Perubahan dan Resiliensi Organisasi (Studi pada Industri Perhotelan di Jawa Timur). Jurnal Aplikasi Manajemen, 8(4), 951-960.

28. Undang-Undang Republik Indonesia Nomor 32 Tahun 2004 Tentang Pemerintahan Daerah, Jakarta: Citra Utama.

29. Wallace, A. (2010). New neighbourhoods, new citizens? Challenging 'community'as a framework for social and moral regeneration under New Labour in the UK. International Journal of Urban and Regional Research, 34(4), 805-819.

30. Wangila, R. N., \& Kiiru, D. (2019). Employee Relations Strategies and Performance of Water and Sewerage Service Provider in Nairobi City County, Kenya. International Journal of Current Aspects, 3(III), 14-27.

31. Yang, C., \& Northcott, D. (2019). Together we measure: Improving public service outcomes via the co-production of performance measurement. Public Money \& Management, 39(4), 253-261. 